\title{
Estimation of genetic parameters and trends for milk fat and protein percentages in Iranian Holsteins using random regression test day model
}

\author{
Hassan Khanzadeh, Navid Ghavi Hossein-Zadeh and Mohammad Naserani \\ Department of Animal Science, Faculty of Agricultural Sciences, University of Guilan, Rasht, Iran
}

\begin{abstract}
The aim of the present study was to estimate the genetic parameters and trends for fat and protein percentages of milk in Iranian Holsteins calving between 2001 and 2010 using the random regression test day model. Data set included 505160 test day records that were collected by the Animal Breeding Centre of Iran. The Legendre polynomial functions of orders $(5,5)$ and $(5,6)$ were chosen to fit the additive genetic and permanent environmental effects of fat and protein percentages, respectively. Estimated heritabilities ranged from 0.053 to 0.232 and 0.111 to 0.259 for fat and protein percentages, respectively. The averages of estimated breeding values were -8.61 and -3.15 and annual genetic trends were $-0.74 \mathrm{~kg}$ and $-0.64 \mathrm{~kg}$ for fat and protein percentages, respectively. Negative genetic trends for fat and protein percentages are likely the result of major emphasis on milk yield in the breeding plan of Iranian Holsteins.
\end{abstract}

Keywords: genetic correlation; genetic progress; dairy cow; productive performance

\section{Introduction}

The aim of animal breeding is to genetically improve livestock populations for production of more efficient animals to guard against future circumstances. Accurate prediction of breeding values of animals is one of the best tools available for maximising response to selection program (Yousefi-Golverdi et al. 2012). To predict the breeding values it is necessary to know the genetic parameters of important traits or to estimate them using a model similar to the 
model of animal evaluation. In the most developed countries, the estimation of variance components from an animal model with restricted maximum likelihood method is spread due to its favourable features and flexibility (Interbull 1992, Kennedy et al. 1988).

In dairy farms, milk traits are recorded at various times along with lactation and each cow is expected to have about ten daily records per lactation. In traditional methods of genetic evaluations the daily tests would be transformed to a measure for the whole lactation and there will be one record for each animal per lactation. This will decrease the amount of data and cause computational parsimony. But nowadays, thanks to the progress in computer hardware technology, the analysis of large amounts of data has become feasible (Abdullahpour et al. 2010, Szyda \& Liu 1999) and then test day models has been developed which can use test day data directly (Abdullahpour et al. 2010).

Some advantages of test day models are a greater flexibility about milk recording programs (Schaeffer et al. 2000), accounting more accurately for environmental factors that affect cows at different stage of lactation at the time of test (Jamrozik \& Schaeffer 1997, Jensen 2001, Schaeffer et al. 2000, Swalve 2000), modelling the shape of the lactation curve (Schaeffer et al. 2000, Silvestre et al. 2005), increasing the accuracy of genetic evaluations, accounting the number of records per cow and the interval between records (Pool \& Meuwissen 1999), decreasing the costs of milk recording by making fewer measurements (Pool \& Meuwissen 1999), flexibility and the potential to slightly reduce the generation interval by frequent genetic evaluations (Swalve 2000).

The random regression model is presented by Henderson in 1982. Schaeffer \& Dekkers (1994) used the random regression model for the analysis of test day milk records. Meyer (2004) showed that increase in the amount of data from each animal and the use of random regression model would increase the accuracy of genetic evaluation. In addition, random regression model describes in a continuous manner the structure of covariances over time and allows the estimation of breeding values for total or partial lactation yield, in contrast to multi-trait models which provide point predictions (Bignardi et al. 2009). In general, the Legendre polynomials have largely been used to fit random curves due to their ability of describing the variation along the period. They also avoid overparameterisation of genetic variances and heritability at the beginning and the end of curves (Brotherstone et al. 2000, López-Romero \& Carabaño 2003, Bignardi et al. 2009). The results in the literature have shown that the parameter estimates are highly influenced by the order of the covariance functions used to describe the trends for the additive genetic and permanent environment effects and by the residual variance structure. (Meyer 1998).

The effect of selection on quantitative traits in genetic structure of population always has been considered by animal breeding experts. One of the ways for this purpose is the study of population genetic trends over the past years. Genetic trend evaluates genetic variations over time and also explains the variations of breeding values over consecutive years. A number of methods is available for estimating genetic trends in dairy cattle populations, using either planned selection experiments or data from commercial herds that use control group, regression method and animal model (Nizamani \& Berger 1996, Yousefi-Golverdi et al. 2012). The precision of genetic trend estimates is enhanced greatly because the number of years, in which it has been studied, increases (Yousefi-Golverdi et al. 2012). 
Although the subject of this study has been investigated by other researchers, the novel items in this study included the use of large data set and the interest of including milk constituents in the analyses. On the other hand, comparison of the current estimates of genetic parameters and trends for milk constituents in Iranian dairy herds with other dairy production systems could be interesting in this study. The aim of the present study was to estimate the genetic trend and genetic analyses of test day fat and protein percentages in Iranian Holstein cattle.

\section{Material and methods}

Data of 505160 daily fat and protein percentage records of the first lactation of Holstein cows with calvings between 2001 and 2010 were obtained from the Animal Breeding Centre of Iran. Records were designated using Foxpro 8.0 and ACCESS 2007 software (Microsoft Corporation, Redmond, WA, USA) and the wrong and unusual records were removed from the dataset. Test day observations before day 5 and after day 400 were discarded. The records of cows were deleted if they had fewer than 8 or more than 12 daily fat and protein percentage records or their ages at first calving were below 20 months or above 36 months. All records belonging to the cows, whose sires had less than ten daughters or their herds comprised less than 150 cows, were removed. The pedigree comprised was including seven generations of sire and dam ancestors. Summaries of the pedigree information and the test day data are presented in Tables 1 and 2, respectively.

Table 1

Summary of the pedigree information

\begin{tabular}{lr}
\hline Variable & Number \\
\hline Number of animals & 125115 \\
Number of animals with record & 54960 \\
Number of sires & 2357 \\
Number of dams & 79937 \\
Number of animals with progeny & 82294 \\
Number of animals with progeny and record & 12139 \\
Number of animals without progeny & 42821 \\
Number of inbred animals & 236 \\
\hline
\end{tabular}

Table 2

Summary of test day information

\begin{tabular}{lrrrrrr}
\hline Test day & Days in milk & Number of records & \multicolumn{2}{c}{ Fat } & \multicolumn{2}{c}{ Protein } \\
& & & Mean & STD & Mean & STD \\
\hline 1 & $5-35$ & 46541 & 3.47 & 0.82 & 3.02 & 0.41 \\
2 & $36-65$ & 49984 & 3.18 & 0.75 & 2.89 & 0.37 \\
3 & $66-95$ & 49362 & 3.15 & 0.74 & 2.93 & 0.36 \\
4 & $96-125$ & 50848 & 3.16 & 0.73 & 2.99 & 0.36 \\
5 & $126-155$ & 49419 & 3.19 & 0.73 & 3.04 & 0.36 \\
6 & $156-185$ & 50816 & 3.24 & 0.72 & 3.07 & 0.36 \\
7 & $186-215$ & 49228 & 3.29 & 0.72 & 3.11 & 0.36 \\
8 & $216-245$ & 50737 & 3.34 & 0.72 & 3.14 & 0.36 \\
9 & $246-275$ & 44801 & 3.41 & 0.72 & 3.18 & 0.36 \\
10 & $>275$ & 63424 & 3.52 & 0.74 & 3.27 & 0.38 \\
Total & $5-305$ & 505160 & 3.29 & 0.75 & 3.07 & 0.38 \\
\hline
\end{tabular}


GLM procedure of SAS v9.1 software (SAS Institute Inc., Cary, NC, USA) was used for fitting the fixed effects in the statistical models of analysis. All analyses were performed using the random regression analyses of the WOMBAT v1.0 software package using AIREML algorithm on a Linux operating system (Meyer 2007).

\section{Model}

The following random regression model was used in the analysis:

$$
\left.Y_{\text {imnptv }}=H T D_{m}+\sum_{f=0}^{2} C_{f}\left(\text { age }_{n}\right)^{f}+\sum_{r=0}^{k} \beta_{r} \Phi_{r}\left(\operatorname{dim}_{t}\right)+\sum_{r=0}^{k_{a-1}} a_{p r} \Phi_{r}\left(\operatorname{dim}_{t}\right)+\sum_{r=0}^{k_{p-1}} \gamma_{p r} \Phi_{r}(\operatorname{dim})_{t}\right)+e_{i m n p t v}
$$

where $Y_{\text {imnptv }}$ is the test day record $i$ obtained at $\operatorname{dim} t$ of cow $p$ calved at the $n$-th age in herdtest date $m, H T D_{m}$ is the fixed effect of $m$-th herd-test date, $C_{f}$ is the $f$-th fixed regression coefficient for calving age, age is the $n$-th calving age, $k$ is the order of fit for fixed regression coefficients $(k=2), \beta_{r}$ is the $r$-th fixed regression coefficient, $k_{a}$ is the order of fit for additive genetic random regression coefficients, $k_{p}$ is the order of fit for permanent environmental random regression coefficients, $a_{p r}$ is the $r$-th random regression coefficient of additive genetic value of $p$-th cow, $\gamma_{p r}$ is the $r$-th random regression coefficient of permanent environmental effect of $p$-th cow, $\Phi_{r}\left(\operatorname{dim}_{t}\right)$ is the $r$-th coefficient of Legendre polynomials evaluated at days in milk $t$ and $e_{m n p t v}$ is the random residual error.

\section{Measures of 305 d yields}

The estimated breeding value (EBV) of animal $p$ for day $t$ was calculated by:

$$
E B V_{p t}=\sum_{r=0}^{k_{a}-1} a_{p v} \varnothing_{j}\left(\operatorname{dim}_{t}\right)
$$

where $E B V_{p t}$ is the breeding value of cow $p$ at $\operatorname{dim} t, a_{p v}$ is the random regression coefficient of additive genetic value of $p$-th cow, $\left(\operatorname{dim}_{t}\right) \Phi$ is the $r$-th coefficient of Legendre polynomials evaluated at days in milk $t$.

Therefore, the EBV of animal $p$ for $305 \mathrm{~d}$ yields was obtained by summing the EBVs from day 5 to day 305.

$$
E B V m=Z C_{305} a_{p}
$$

where $a_{p}$ is the random regression coefficient of additive genetic value of $p$-th cow and $Z C_{305}$ is a vector of the summations of Legendre polynomials corresponding to total lactation milk production. $\mathrm{ZC}_{305}$ was used for both traits under study as follows: $\mathrm{ZC}_{305}=\left[\begin{array}{ll}212.84 & -88.66\end{array}\right.$ -58.49-13.04 22.25]

After predicting the breeding values of animals for $305 \mathrm{~d}$ yields, the genetic trends of test day fat and protein percentages were calculated using the regression of the means of breeding values on the years. Genetic trend analyses were performed with the regression procedure of the SAS v9.1 software package (SAS Institute Inc., Cary, NC, USA). 


\section{Results and discussion}

In order to achieve the appropriate random regression model for the analysis of test day fat and protein percentages with the minimum number of parameters to estimate additive genetic and permanent environmental parameters, different orders of fit for random regression coefficients of additive genetic and permanent environmental effects were evaluated. These models are presented in Table 3.

Table 3

Different orders of fit for random regression coefficients in this study

\begin{tabular}{llcccc}
\hline Model & \multicolumn{2}{c}{ Order of fit } & $\mathrm{np}$ & $\operatorname{logl}_{\text {fat }}$ & log $_{\text {protein }}$ \\
\hline 1 & $\mathrm{ka}$ & $\mathrm{kpe}$ & & & \\
2 & 3 & 3 & 13 & -39354.590 & 402203.760 \\
3 & 3 & 4 & 17 & -38283.342 & 404519.719 \\
4 & 3 & 5 & 22 & -37428.645 & 407466.956 \\
5 & 3 & 6 & 28 & -37015.541 & 409554.583 \\
6 & 4 & 4 & 21 & -36534.795 & 406060.751 \\
7 & 4 & 5 & 26 & -36021.878 & 408193.033 \\
8 & 4 & 6 & 32 & -35659.164 & 410164.437 \\
9 & 5 & 5 & 31 & -35293.538 & 410601.607 \\
\hline
\end{tabular}

ka, kpe: orders of fit for additive genetic and permanent environmental effects, respectively; np: number of parameter for estimated variance function; logl: maximum log likelihood

In models with different orders of fit for additive genetic and permanent environmental effects, the increase in the maximum log likelihood improved the fit of the model and reduced the residual variances (Liu et al. 2006, Meyer 2000, Sesana et al. 2010). In the present study, estimates of residual variance decreased as the order of the model increased. Models 8 and 9 were chosen to fit the additive genetic and permanent environmental effects for the analysis of fat and protein percentages, respectively. The maximum log likelihood of model 8 for fat had significant difference with other models, but this model had no significant difference with model 9 , considering the higher order of fit for the random effects in model 9. Therefore, the Legendre polynomial functions of orders $(5,5)$ and $(5,6)$ were chosen to fit the additive genetic and permanent environmental effects of fat and protein percentages, respectively.

\section{Parameters}

Estimates of additive genetic and permanent environmental (co)variances of random regression coefficients for test day fat and protein percentages are presented in Tables 4 and 5 , respectively.

As indicated in Figure 1, additive genetic and permanent environmental variances had the highest amounts in the early days of lactation for fat. For protein percentage, additive genetic variances increased in the first and last days of lactation (Figure 2), whereas permanent environmental variances were the highest at the beginning of lactation. Based on the results of Meyer et al. (2004) and Zavadilová et al. (2005) on Holstein cows, the highest additive genetic and permanent environment variances for dairy traits occurred in the first and last days of lactation (Interbull 1992). 
Table 4

Estimates of genetic and permanent environmental variances (diagonal), covariances (below diagonal) and correlations (above diagonal) for random regression coefficients of test day fat percentage

\begin{tabular}{ccccccccccccc}
\hline & \multicolumn{4}{c}{ Additive genetic coefficients } & \multicolumn{4}{c}{ Permanent environmental coefficients } \\
& $\mathrm{a}_{0}$ & $\mathrm{a}_{1}$ & $\mathrm{a}_{2}$ & $\mathrm{a}_{3}$ & $\mathrm{a}_{4}$ & & $\mathrm{P}_{0}$ & $\mathrm{P}_{1}$ & $\mathrm{P}_{2}$ & $\mathrm{P}_{3}$ & $\mathrm{P}_{4}$ \\
\hline $\mathrm{a}_{0}$ & $\mathbf{0 . 0 6 4 7}$ & 0.4200 & -0.3918 & 0.2743 & -0.2789 & $\mathrm{P}_{0}$ & $\mathbf{0 . 0 5 9 5}$ & 0.1030 & -0.1329 & -0.3541 & 0.0909 \\
$\mathrm{a}_{1}$ & 0.001 & $\mathbf{0 . 0 0 8 7}$ & 0.0580 & 0.2831 & -0.2789 & $\mathrm{P}_{1}$ & 0.0041 & $\mathbf{0 . 0 2 6 2}$ & 0.0201 & -0.1616 & 0.0318 \\
$\mathrm{a}_{2}$ & -0.0068 & 0.0004 & $\mathbf{0 . 0 0 4 6}$ & -0.3908 & 0.3661 & $\mathrm{P}_{2}$ & -0.0045 & 0.0004 & $\mathbf{0 . 0 1 9}$ & -0.4044 & 0.4321 \\
$\mathrm{a}_{3}$ & 0.0062 & 0.0023 & -0.0024 & $\mathbf{0 . 0 0 7 8}$ & -0.9930 & $\mathrm{P}_{3}$ & -0.0055 & -0.0016 & -0.0035 & $\mathbf{0 . 0 0 4}$ & 0.3864 \\
$\mathrm{a}_{4}$ & 0.0061 & -0.0022 & 0.0022 & -0.0076 & $\mathbf{0 . 0 0 7 4}$ & $\mathrm{P}_{4}$ & 0.0021 & 0.0005 & 0.0057 & 0.0023 & $\mathbf{0 . 0 0 9 3}$ \\
\hline
\end{tabular}

Table 5

Estimates of genetic and permanent environmental variances (diagonal), covariances (below diagonal) and correlations (above diagonal) for random regression coefficients of test day protein percentage

\begin{tabular}{|c|c|c|c|c|c|c|c|c|c|c|c|c|}
\hline \multicolumn{7}{|c|}{ Additive genetic coefficients } & \multicolumn{6}{|c|}{ Permanent environmental coefficients } \\
\hline & $a_{0}$ & $a_{1}$ & $a_{2}$ & $a_{3}$ & $a_{4}$ & & $P_{0}$ & $P_{1}$ & $P_{2}$ & $\mathrm{P}_{3}$ & $\mathrm{P}_{4}$ & $\mathrm{P}_{5}$ \\
\hline$a_{0}$ & 0.0219 & 0.5482 & -0.3398 & -0.2572 & -0.0473 & $\mathrm{P}_{0}$ & 0.0150 & 0.2046 & 0.0653 & -0.0608 & -0.0880 & -0.1156 \\
\hline$a_{1}$ & 0.0069 & 0.0072 & -0.0821 & -0.2630 & 0.0175 & $p_{1}$ & 0.0021 & 0.0067 & 0.2211 & 0.2298 & -0.6627 & 0.0290 \\
\hline$a_{2}$ & -0.0017 & -0.0002 & 0.0011 & -0.6723 & 0.5789 & $\mathrm{P}_{2}$ & 0.0006 & 0.0013 & 0.0050 & 0.1995 & -0.1039 & -0.0748 \\
\hline$a_{3}$ & -0.0005 & -0.0003 & -0.0003 & 0.0002 & -0.4506 & $P_{3}$ & -0.0006 & 0.0015 & 0.0011 & 0.0065 & 0.5517 & 0.6706 \\
\hline$a_{4}$ & -0.0004 & 0.0001 & 0.0011 & -0.0003 & 0.0032 & $\begin{array}{l}P_{4} \\
P_{5}\end{array}$ & $\begin{array}{l}-0.0002 \\
-0.0010\end{array}$ & $\begin{array}{r}-0.0012 \\
0.0002\end{array}$ & $\begin{array}{l}-0.0002 \\
-0.0004\end{array}$ & $\begin{array}{l}0.0065 \\
0.0038\end{array}$ & $\begin{array}{l}0.0005 \\
0.0007\end{array}$ & $\begin{array}{l}0.4322 \\
0.0051\end{array}$ \\
\hline
\end{tabular}
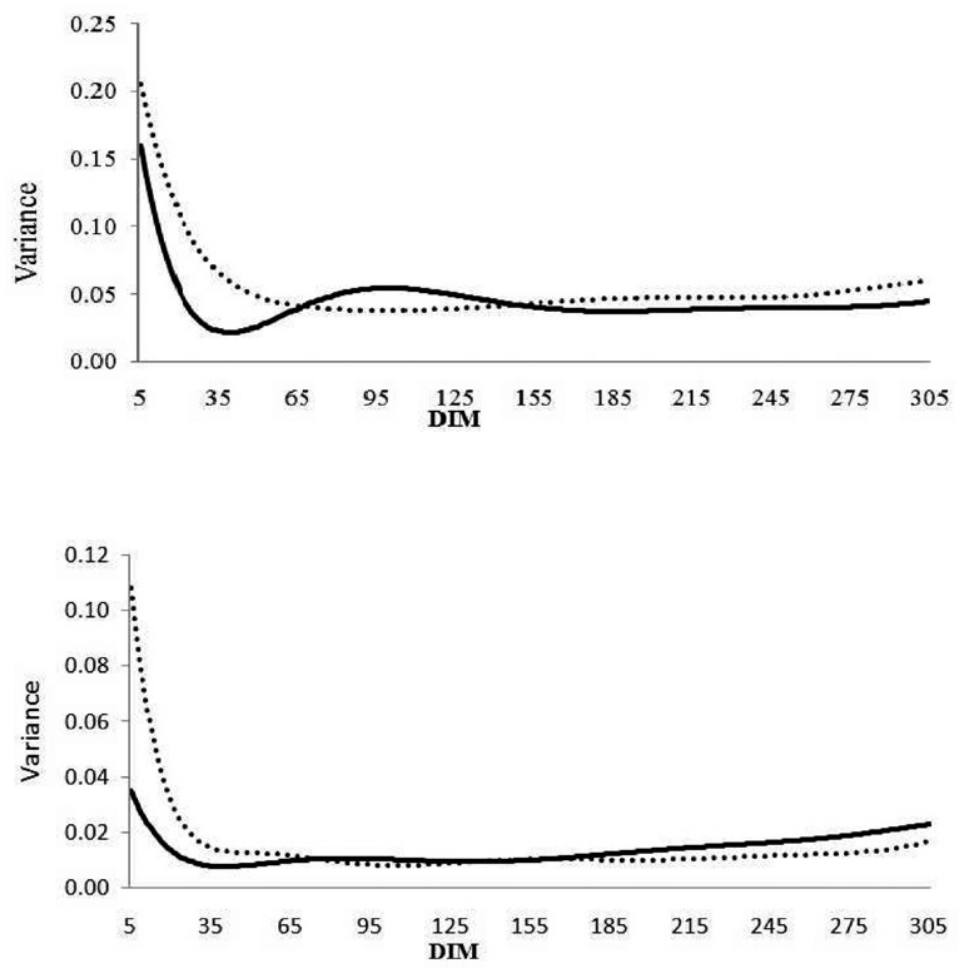

Figure 1

Additive genetic (line) and permanent environmental variances (dash) for test day fat percentage over the lactation
Figure 2

Additive genetic (line) and permanent environmental variances (dash) for test day protein percentage over the lactation 


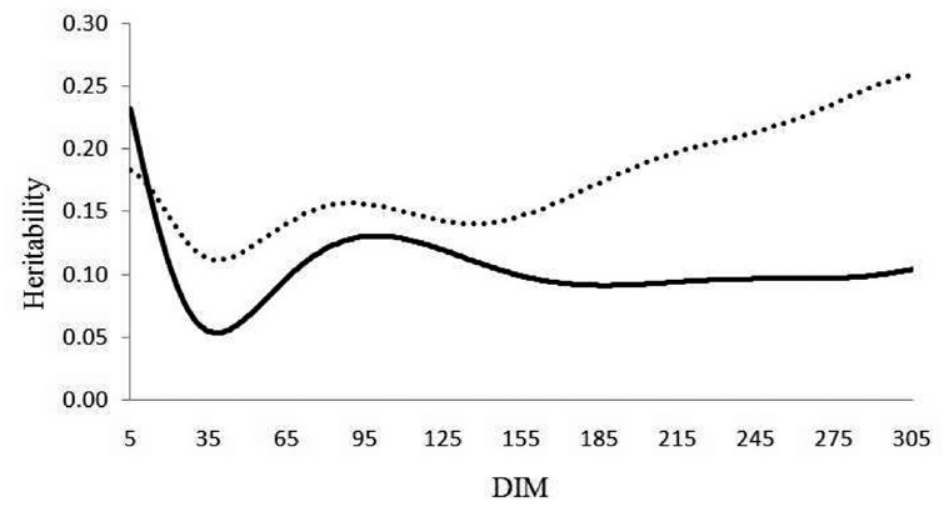

Figure 3

Heritability estimates for fat (line) and protein (dash) percentages during lactation

Estimates of heritabilities for fat and protein percentages are presented in Figure 3 . Heritability estimates for daily fat and protein percentage records ranged from 0.053 to 0.232 for fat percentage and 0.111 to 0.259 for protein percentage. Repeatability estimates for these traits ranged from 0.187 to 0.529 and 0.272 to 0.745 , respectively. Abdullahpour et al. (2010) reported on heritabilities of 0.07 to 0.11 and 0.11 to 0.18 and repeatabilities of 0.12 to 0.19 and 0.17 to 0.28 for fat and protein percentages, respectively. Jamrozik \& Schaeffer (1997) reported on heritabilities of 0.10 and 0.25 for fat and protein yields, respectively. The heritability estimate for fat percentage was the highest at the beginning of lactation and the heritability estimate for protein percentage was the highest at the end of lactation.

In the present study, the heritability estimates for fat percentage were lower than those for protein percentage over the lactation. Consistent with the current results, Abdullahpour et al. (2010), DeGroot et al. (2007), Druet et al. (2004), Hammami et al. (2008) and Silvestre et al. (2005) reported lower heritability estimates for milk fat during lactation. The characteristics of fat in the way of being much influenced by temporary environmental effects may be the main reason for its lower heritability (Abdullahpour et al. 2010). In addition, since the determination of milk fat and protein percentage requires the application of special laboratory equipment, any measurement error in calculating the percentage of milk fat and protein samples increases the error variance and thus reduces the estimate of heritability for the trait. Estimated parameters for $305 \mathrm{~d}$ yields are presented in Table 6 .

Table 6

$305 \mathrm{~d}$ yield parameters for fat and protein percentages in this study

\begin{tabular}{lccccccc}
\hline & $\begin{array}{c}\text { Additive } \\
\text { genetic } \\
\text { variance }\end{array}$ & $\begin{array}{c}\text { Permanent } \\
\text { environmental } \\
\text { variance }\end{array}$ & $\begin{array}{c}\text { Residual } \\
\text { variance }\end{array}$ & $\begin{array}{c}\text { Phenotypic Heritability } \\
\text { variance }\end{array}$ & Repeatability & Mean of EBV \\
\hline fat & 13.23 & 16.17 & 97.83 & 127.24 & 0.10 & 0.23 & -8.61 \\
protein & 4.05 & 4.26 & 14.73 & 23.05 & 0.18 & 0.36 & -3.15 \\
\hline
\end{tabular}

\section{Genetic trends}

The annual genetic trends (standard error) for milk fat and protein percentages in Iranian Holstein cattle were $-0.74 \mathrm{~kg}(0.054)$ and $-0.64 \mathrm{~kg}(0.033)$, respectively. Genetic trends were 
negative and significant $(P<0.01)$ for both traits. Estimates of genetic trends for both traits are presented in Figure 4. Abdullahpour et al. (2010) also reported on negative genetic trends for milk fat and protein percentages in Iranian Holsteins. Negative genetic trends for fat and protein percentages are likely the result of major emphasis on milk yield and neglecting fat and protein percentages in the sire selection at the level of farms during past years. This condition could cause a correlated response for fat and protein percentages as the result of selection for milk because of the probably negative correlation between milk yield and milk fat and protein (Abdullahpour et al. 2010). Hashemi \& Nayebpoor (2008) reported on negative genetic correlation between milk yield and fat and protein percentages in Iranian Holstein population. Freitas et al. (1995) estimated a genetic trend of -0.22 and $-0.21 \mathrm{~kg}$ for fat and protein yields in the Brazilian dairy cattle. Kunaka \& Makuza (2005) reported on genetic trends of 0.127 and $0.39 \mathrm{~kg}$ for fat and protein yields. These reports are in contrast with the results of the present study. This discrepancy is probably due to the difference between years of procurement records for these studies. Phenotypic trends (standard error) for fat and protein percentages in this study were $-0.007 \mathrm{~kg}(0.0004)$ and $-0.003 \mathrm{~kg}(0.0002)$, respectively. The phenotypic trend (figure 5 ) for both traits was negative and significant $(P<0.01)$. Considering the negative phenotypic trends for the traits in this study, negative genetic trends did not seem unreasonable.
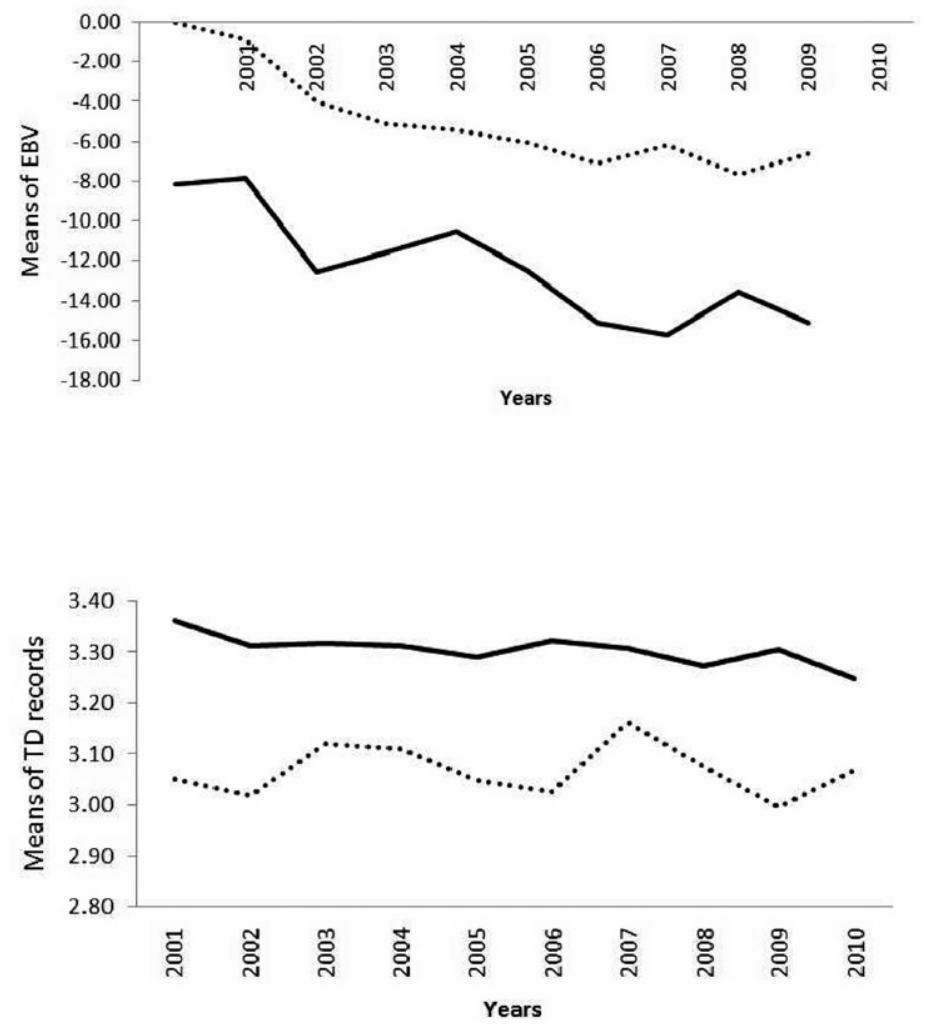

Figure 4

Genetic trend for fat (line) and protein (dash) percentages

\section{Figure 5}

Phenotypic trend for fat (line) and protein (dash) percentages 
In conclusion, the results of the present study indicate that heritability of fat percentage was the highest in the beginning days, third and fourth months of lactation and heritability of protein was the highest in the last months of lactation. Therefore, it was suggested to select for these traits in these periods of lactation. The relatively low heritability estimates obtained in this study indicate that studied traits are more influenced by environmental factors than by genetic effects. Negative genetic trends for fat and protein percentages are likely the result of major emphasis on milk yield and neglecting fat and protein percentages in the sire selection at the level of farms during past years. Therefore, studied traits have not been considered to be improved in the breeding program.

\section{Acknowledgements}

Authors wish to acknowledge the Animal Breeding Centre of Iran for providing the data used in this study.

\section{References}

Abdullahpour R, Moradi Shahrbabak M, Nejati-Javaremi A, Vaez Torshizi R (2010) Genetic Analysis of Daily Milk, Fat Percentage and Protein Percentage of Iranian First Lactation Holstein Cattle. World Appl Sci J 10, 1042-1046

Bignardi AB, El Faro L, Cardoso VL, Machado PF, de Albuquerque LG (2009) Random regression models to estimate test-day milk yield genetic parameters Holstein cows in Southeastern Brazil. Livest Sci 123, 1-7

Brotherstone S, White IMS, Meyer K (2000) Genetic modelling of daily yield using orthogonal polynomials and parametric curves. Anim Sci 70, 407-415

DeGroot BJ, Keown JF, Van Vleck LD, Kachmen SD (2007) Estimation of genetic parameters for Holstein cows for test-day yield traits with a random regression cubic spline model. Genet Mol Res 6, 434-444

Druet T, Jaffrézic F, Ducrocq V (2004) Estimation of genetic parameters for test day records of dairy traits in the first three lactations. Genet Sel Evol 37, 257-271

Freitas JA, Silva RAG, Nascimento JAC (1995) [Características do leite fluido consumido em Belém, Pará]. Arq Bras Med Vet Zootec 47, 435-445 [in Portuguese]

Hashemi A, Nayebpoor M (2008) Estimation of Genetic and Phenotype Parameters for Milk Production in Iran Holstein-Friesian Cows. Res J Biol Sci 3, 678-682

Henderson CR Jr. (1982) Analysis of Covariance in the Mixed Model: Higher-Level, Nonhomogeneous, and Random Regressions. Biometrics 38, 623-640

Hammami H, Rekik B, Soyeurt H, Ben Gara A, Gengler N (2008) Genetic Parameters for Tunisian Holsteins Using a Test-Day Random Regression Model. J Dairy Sci 91, 2118-2126

Interbull (1992) Sire evaluation procedures for dairy production traits practiced in various countries. Bulletin No. 5. Department of animal breeding and genetics, SLU, Uppsala, Sweden

Jamrozik J, Schaeffer LR (1997) Estimation of Genetic Parameters for a Test Day Model with Random Regressions for Yield Traits of First Lactation Holsteins. J Dairy Sci 80, 762-770

Jensen J (2001) Genetic Evaluation of Dairy Cattle Using Test-Day Models. J Dairy Sci 84, 2803-2812

Kennedy BW, Schaeffer LR, Sorensen DA (1988) Genetic Properties of Animal Models. J Dairy Sci 71, 17-26

Kunaka K, Makuza SM (2005) Genetic and Environmental Trends for Milk Traits in the Zimbabwean HolsteinFriesian Population. PJBS 8, 1011-1015

Liu YX, Zhang J, Schaeffer LR, Yang RQ, Zhang WL (2006) Optimal Random Regression Models for Milk Production in Dairy Cattle. J Dairy Sci 89, 2233-2235 
López-Romero P, Carabaño MJ (2003) Comparing alternative random regression models to analyse first lactation daily milk yield data in Holstein-Friesian cattle. Livest Prod Sci 82, 81-96

Mayeres P, Stool J, Boormann J, Reents R, Gengler N (2004) Prediction of daily milk, fat, and protein production by a random regression test-day model. J Dairy Sci 87, 1925-1933

Meyer K (2007) WOMBAT - A tool for mixed model analyses in quantitative genetics by restricted maximum likelihood (REML). J Zhejiang Univ Sci B. 2007 November; 8 (11), 815-821

Meyer K (1998) Estimating covariance functions for longitudinal data using a random regression model. Genet Sel Evol 30, 221-240

Meyer K (2004) Scope for a random regression model in genetic evaluation of beef cattle for growth. Livest Prod Sci 86, 68-83

Meyer K (2000) Random regressions to model phenotypic variation in monthly weights of Australian beef cows. Livest Prod Sci 65, 19-38

Nizamani AH, Berger PJ (1996) Estimates of Genetic Trend for Yield Traits of the Registered Jersey Population. J Dairy Sci 79, 487-494

Pool MH, Meuwissen THE (1999) Prediction of Daily Milk Yields from a Limited Number of Test Days Using Test Day Models. J Dairy Sci 82, 1555-1564

Schaeffer LR, Jamrozik J, Kistemaker GJ, Van Doormaal J (2000) Experience with a Test-Day Model. J Dairy Sci $83,1135-1144$

Schaeffer LR, Dekkers JCM (1994) Random regressions in animal models for test-day production in dairy cattle. In: Proc 5th World Congr Genet Appl Livest Prod 18, Guelph, Ontario, Canada, 182-186

Sesana RC, Bignardi AB, Borquis RRA, El Faro L, Baldi F, Albuquerque LG, Tonhati H (2010) Random regression models to estimate genetic parameters for test-day milk yield in Brazilian Murrah buffaloes. J Anim Breed Genet 127, 369-376

Silvestre AM, Petim-Batista F, Colaço J (2005) Genetic Parameter Estimates of Portuguese Dairy Cows for Milk, Fat and Protein Using a Spline Test-Day Model. J Dairy Sci 88, 1225-1230

Swalve HH (2000) Theoretical Basis and Computational Methods for Different Test-Day Genetic Evaluation Methods. J Dairy Sci 83, 1115-1124

Szyda J, Liu Z (1999) Modelling test day data from dairy cattle. J Appl Genet 40, 103-116

Yousefi-Golverdi A, Hafezian H, Chashnidel Y, Farhadi A (2012) Genetic parameters and trends of production traits in Iranian Holstein population. Afr J Biotechnol 11, 2429-2435

Zavadilová L, Jamrozik J, Schaeffer LR (2005) Genetic parameters for test-day model with random regressions for production traits of Czech Holstein cattle. Czech J Anim Sci 50, 142-154 